\title{
Development of a Mechanism for the Management of University Research Activities Based on the Principles of Sustainable Development
}

\author{
Natalia Ketoeva*, Maria Kiseleva, and Victoria Dranitsyna \\ National Research University "Moscow Power Engineering Institute", Moscow, Russia
}

\begin{abstract}
The article is devoted to the topical issues of performance evaluation and management of university research groups for its sustainable development. Scientific groups are one of the effective levers for increasing and activation of research activities in the university, as they cover all areas of its activities: performance of research and development work, building a portfolio of orders, preparation of applications for intellectual property objects, preparation of articles and reports, training of highly qualified personnel and implementation of expert activities. To develop a methodology for assessing the effectiveness of research teams, the existing methods for analyzing the management of research activities of universities in Russian and world practice were considered, where their advantages and disadvantages were identified. The university's organizational and economic mechanism of research activities management was developed based on the above and the principles of sustainable development of higher education institutions.
\end{abstract}

\section{Introduction}

Currently, the fourth industrial revolution is based on the extensive use of human capital and high technology. The main component of creating breakthrough technologies is research and development $(\mathrm{R} \& \mathrm{D})$. The current research is to develop a model of interaction of university departments as a business unit, with all objects of the educational services market, as well as related markets.

Thus, the study aims to develop an organizational and economic mechanism for the management of research activities in the university.

To achieve this goal, the following tasks were set and solved:

- to characterize the management of research activities in the university;

- to consider methods of assessment of R\&D management in Russian and world practice;

- to develop a mechanism for managing research activities in the university.

\section{Research Methodology}

*Corresponding author: nhl76@mail.ru 
The research was based on the following methods: dialectical scientific cognition and particular scientific (analysis, synthesis, comparison, logical and system-structural analysis, formalization, analysis of normative-legal documents), modeling.

\section{Findings}

As part of the review of the research literature, the works of the following authors were analyzed: Ponomareva E. V., Ganicheva A.V., as well as foreign works authored by O. I. Vaganova, A. V. Lapshova, M. M. Kutepov, A. Biloshchytskyi, A. Kuchansky, Yu. Andrashko, D. S. Tereshchenko et al. [3,4,5,6,9,10,14]

During the analysis of scientific papers, shortcomings in the effectiveness of R\&D activities were identified, and, based on this, a new mechanism of R\&D management was developed.

The economic and political situation in the world, acceleration of the scientific and technological process allows us to consider education and competitive human capital as the most important resources for the country's development. The transition of higher education in Russia to a multi-level system of training, as well as the growing requirements of employers to graduates of higher education institutions, necessitate changes in the content of training specialists, bachelors, masters, and postgraduates, the sphere of professional activity of which is the system of higher education. These changes are reflected in the thirdgeneration educational standards, which are based on the competency-based approach, orienting the participants of the educational process to the formation of competencies personal qualities necessary for independent professional and research activities. Thus, there is a need to maintain and actively develop students' research activities [8].

In this regard, a new organizational and economic mechanism of university research activities management is formed, which is the integration of organizational and economic mechanisms, which include organizational and economic methods, levers, tools of influence on the managed object.

\section{Discussion}

The future specialist should combine the abilities of a scientist, a designer, and a manager, be able to unite specialists of different profiles for joint work. Thus, nowadays, a graduate of a higher education institution, who aims to find creative solutions to professional problems, i.e., who has a high level of professional and creative competencies, is of interest to society and employers in the labor market.

In the federal state educational standards of higher education (FSES HE), research activities are included in the content of professional training of specialists, bachelors, masters, and undergraduate students and should promote the professional and creative development of students, acting as a platform for effective communication of subjects of the educational process and ensuring the implementation of social order for the training of a competent professional. According to the Federal State Statistics Service, the number of institutions engaged in scientific activities decreases every year $(4,175,4,032$, and 3,944 in recent years). [15]

The Federal Law "On Science and State Scientific and Technological Policy" interprets the definition of research activities as follows: scientific (research) activities or

Research and Development (R\&D) activities are activities aimed at obtaining and applying new knowledge. [1] Research and development activities are divided into two components presented in Figure 1. 


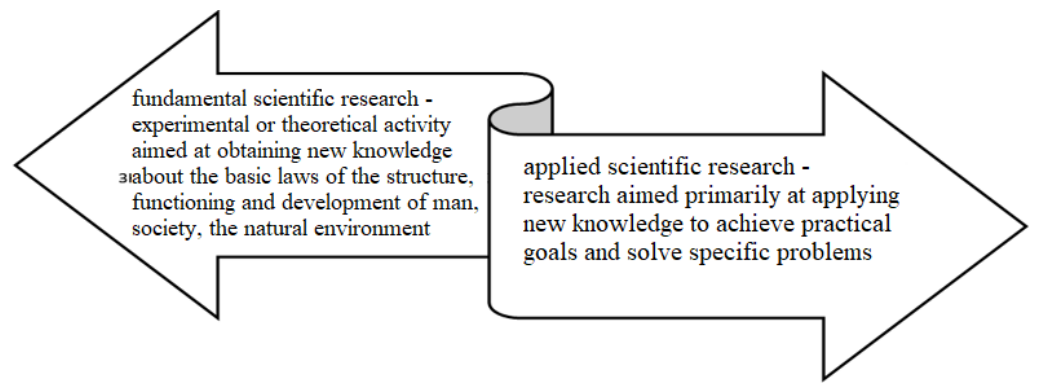

Fig. 1. Classification of research activities

It is worth noting that the effectiveness of $R \& D$ activities can be assessed on the basis of two criteria:

- the quality of research work conducted at the university;

- correspondence of research works to the problem orientation of the university.

Let us compare the indicators used in assessing scientific activity in different countries (Table 1). [12]

Table 1. Indicators for assessing scientific performance in different countries.

\begin{tabular}{|c|c|c|c|c|c|c|}
\hline \multirow[b]{2}{*}{ Indicators } & \multicolumn{6}{|c|}{ Country } \\
\hline & 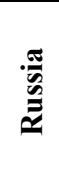 & 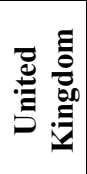 & 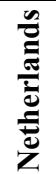 & 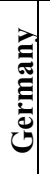 & 总 & $\begin{array}{l}\vec{z} \\
\overrightarrow{0} \\
z\end{array}$ \\
\hline Publications and citations in various databases & $\mathrm{V}$ & $\mathrm{V}$ & $\mathrm{V}$ & $\mathrm{V}$ & $\mathrm{V}$ & $\mathrm{V}$ \\
\hline Revenue from R\&D at the university & $\mathrm{V}$ & V & $\mathrm{V}$ & $\mathrm{V}$ & $\mathrm{V}$ & $\mathrm{V}$ \\
\hline Grants received by the university & $\mathrm{V}$ & $\mathrm{V}$ & $\mathrm{V}$ & $\mathrm{V}$ & $\mathrm{V}$ & $\mathrm{V}$ \\
\hline License agreements received by the university & $\mathrm{V}$ & $\mathrm{V}$ & $\mathrm{V}$ & $\mathrm{V}$ & $\mathrm{V}$ & $\mathrm{V}$ \\
\hline Number of foreign students studying at the university & $\mathrm{X}$ & V & $\mathrm{X}$ & $\mathrm{V}$ & $\mathrm{X}$ & V \\
\hline $\begin{array}{l}\text { Funds received by the educational organization from the use of } \\
\text { the results of intellectual activity }\end{array}$ & $\mathrm{V}$ & V & V & $\mathrm{V}$ & $\mathrm{V}$ & V \\
\hline Patents, inventions registered at the university & $\mathrm{X}$ & $\mathrm{V}$ & $\mathrm{V}$ & $\mathrm{V}$ & $\mathrm{V}$ & $\mathrm{V}$ \\
\hline $\begin{array}{l}\text { Number of teachers from other countries teaching at the } \\
\text { university }\end{array}$ & $\mathrm{X}$ & V & $\mathrm{V}$ & $\mathrm{V}$ & $\mathrm{V}$ & V \\
\hline $\begin{array}{l}\text { Number of international research projects in which the university } \\
\text { participates }\end{array}$ & $\mathrm{X}$ & V & V & $\mathrm{V}$ & V & V \\
\hline $\begin{array}{l}\text { Indicators that characterize the position of the university in } \\
\text { various rankings }\end{array}$ & $X$ & $X$ & V & $\mathrm{V}$ & V & $\mathrm{V}$ \\
\hline $\begin{array}{l}\text { Self-evaluation conducted by the university in the field of } \\
\text { research activities }\end{array}$ & $X$ & $X$ & V & $\mathrm{X}$ & $\mathrm{V}$ & V \\
\hline
\end{tabular}

Table 1 shows similar indicators of Russia and foreign countries. These are publications and citations in various databases, income from $\mathrm{R} \& \mathrm{D}$, grants and license agreements received by the educational organization, as well as funds received by the educational organization from the use of results of intellectual activity and the number of patents, inventions. These indicators are used in the assessment in all countries under consideration.

It is worth noting that none of the countries take into account the performance of research teams when evaluating the research activities of an educational institution.

Scientific teams should primarily be formed on the basis of a competency-based approach, i.e. in terms of mastery of a skill and experience in a particular field. This is one of the most modern methods of group formation in education and, according to the author, 
the most effective. The competency-based approach contains the following components (Figure 2):

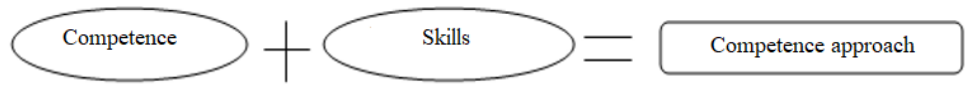

Fig. 2. Components of the competence approach

The concept of "competence" is more often referred to as functional areas of activity, and "competence" - to behavioral areas.

The structure of competence is known to consist of three components [16]:

- cognitive component (know), which is a system of declarative (know "what"), procedural (know "how") and methodological (know "how to know") knowledge in a particular area;

- motivation-value component (attitude, aspiration), allowing to correlate the reflected professional reality with the views, perceptions, and beliefs;

- activity-based component (be able, possess) consists of general scientific and professionally-oriented skills that contribute to the acquisition of activity experience in the use of this field of knowledge or technology in professionally significant situations. [17] The structure of competence includes the following elements: theoretical knowledge, skills, and abilities. The results of the competence analysis are formed in Table 2:

Table 2. Analysis of the elements of competence of the members of the scientific team.

\begin{tabular}{|c|c|c|}
\hline No. & Element & Element description \\
\hline 1. & $\begin{array}{l}\text { Performance } \\
\text { algorithm }\end{array}$ & $\begin{array}{l}\text { The sequence of activities and their nature that is optimal to } \\
\text { achieve the planned result under the given conditions }\end{array}$ \\
\hline 2. & $\begin{array}{l}\text { Theoretical } \\
\text { knowledge }\end{array}$ & $\begin{array}{l}\text { Systematic information about the activities performed, as well } \\
\text { as their conditions, objects, and subjects. }\end{array}$ \\
\hline 3. & $\begin{array}{l}\text { Psychological } \\
\text { attitudes }\end{array}$ & $\begin{array}{l}\text { Understanding of the meaning of the activity, positive attitude } \\
\text { towards it, confidence in one's own abilities. }\end{array}$ \\
\hline 4. & Skills and abilities & $\begin{array}{l}\text { A set of relevant actions that enable the implementation of an } \\
\text { effective action algorithm. }\end{array}$ \\
\hline 5. & $\begin{array}{c}\text { Personal and } \\
\text { professional qualities }\end{array}$ & $\begin{array}{l}\text { Ensure the quality and often the very feasibility of all the } \\
\text { actions performed. }\end{array}$ \\
\hline 6. & $\begin{array}{c}\text { Professional } \\
\text { experience }\end{array}$ & $\begin{array}{l}\text { Provides stability and economical implementation of the } \\
\text { chosen activity algorithm, especially under difficult conditions } \\
\text { (against the background of fatigue, in the presence of } \\
\text { interference, after long pauses, etc.). }\end{array}$ \\
\hline
\end{tabular}

The competence-based approach is a result-oriented approach to education, where the result is not the amount of information learned, but a person's ability to act in different problematic situations.

In essence, the competency-based approach allows [16]:

- understand the development level of each employee at any given time;

- see the dynamics of this development and initiate measures to encourage and promote high-potential employees;

- evaluate the effectiveness of the conducted activities and stimulate the work on the implementation of individual plans and methods of development of each employee.

As applied to the competency-based approach in education, it establishes a new type of educational outcomes, not reducible to a combination of information and skills, but focused on the ability and readiness of individuals to solve various kinds of problems in their activities. 
Contemporary sources indicate that competence is not reducible only to the acquisition and use of information but includes (Figure 3):

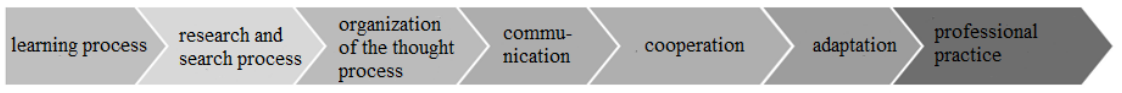

Fig. 3. Key competencies in education.

Let us consider them in more detail:

- the process of learning, and further the competence is the ability to turn knowledge into experience and experience into activity; to generalize and systematize knowledge; to organize one's own scientific and educational process, to be able to solve problems of different nature, to take responsibility for one's education;

- research and inquiry processes, and further the competence is the ability to work with various sources of information, with textbooks and other publications, mastering the basics of scientific organization of work;

- organization of the thinking process: to see the relationship between phenomena, transfer of knowledge, evaluation of various phenomena of reality, works of art, the ability to analyze events, compare, etc.

- communication: skills of speaking in the classroom, listening and speaking, defending your point of view, ability to express your thoughts orally and in writing;

- cooperation: the ability to work in a team, cooperate, resolve conflicts, conduct monologue, dialogue, and polylogue, establish contacts; [18]

- adaptation: the ability to adapt to changing conditions, to use information quickly and learn new information in a short time, to implement new ideas, to be psychologically resistant to difficulties;

- professional practical activity: competently make programs and projects of one's professional activity, take responsibility, be able to organize one's own work, model professional activity. [16]

In this regard, it is necessary to develop a new organizational and economic mechanism for the management of research activities of the university, which will have the ability to assess the research activities based on the analysis of performance indicators of scientific groups. [2,7] 
The organizational and economic mechanism of research activity management in the university is presented in Figure 4.

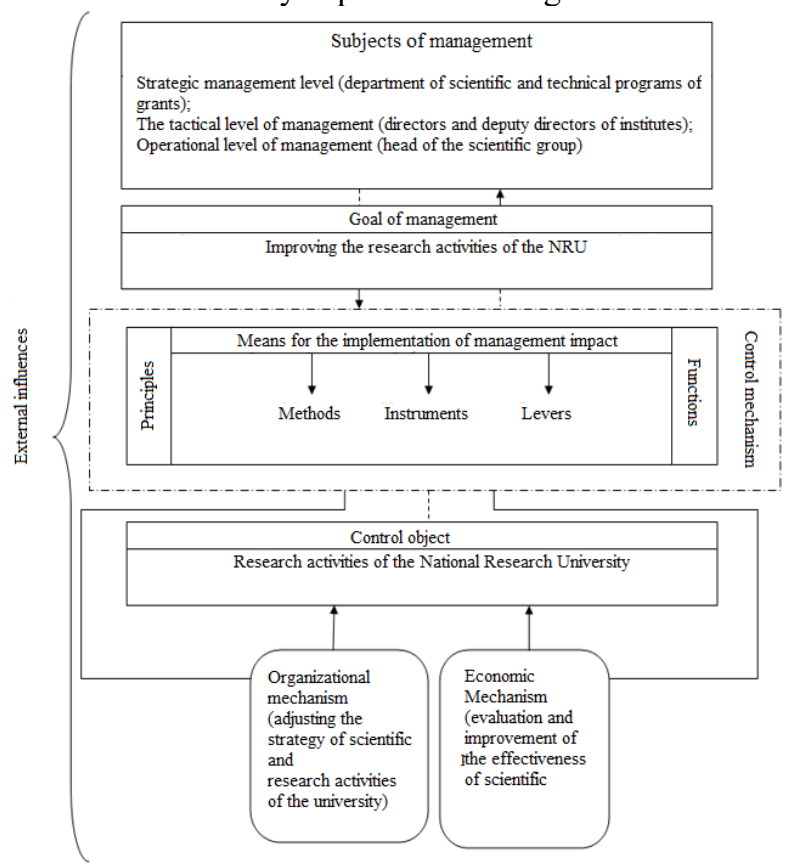

Fig. 4. The organizational and economic mechanism of management of research activities in the university.

The object of management is higher education institutions.

The purpose of this mechanism is to improve the management of research activities of the university.

The mechanism to be developed should perform a number of functions:

- planning of indicators of research activities of a national research university;

- organization of research activities of a national research university;

- motivation of employees and students to perform research and development activities;

- control over the implementation of indicators of research activities and comparison of actual indicators with the planned ones;

- coordination of R\&D activities by responsible persons at all stages of its implementation.

The problem of managing research activities in the university is seen in the fact that during the formation of scientific groups their activities are often formal and not connected with each other. For example, the timing and number of project submissions, their publication activity is only short-term. Thus, OEM management aims to improve the research activities of a national research university, and the object of management is the research activities of a national research university. [11]

With the help of the proposed organizational and economic mechanism, the work of research groups and, as a consequence, the research activity of the university itself is intensified.

The subjects of management in the proposed mechanism are the strategic, tactical, and operational levels of management.

Strategic level of management. At this level, the preparation and collection of information for the development and adoption of a management decision are carried out. The necessary information is collected and processed by the department of scientific and technical programs and grants of the university. Possible options for leaders and members 
of research teams are formed using a system of criteria for the implementation of S\&T programs and grants. This information is transmitted to the tactical control level

The tactical level of management - directors and deputy directors of institutes. An effective management decision is developed and made. At this management level, institute directors and deputy directors for scientific activities evaluate the proposed options for scientific team leaders and members using the model for selecting a scientific team leader and members. After evaluating the options, the best option(s) is selected, and responsible persons are assigned to coordinate the work of the research teams. Such a person may be the head of the department or one of the research team members. The management decision taken is communicated to the head of the department(s) and staff, where a research group or groups are subsequently formed.

Operational level of management - head of the scientific group (or groups). An effective management decision is implemented. The formed research team(s) will prepare an application to participate in the project competition. If the tender is won, the project is subsequently carried out. The coordination of the scientific team's activities by the person appointed at the tactical management level is mandatory. If necessary, adjustments are made to the scientific team's activities. For example, optimizing project timelines or project submissions due to deviations from deadlines, or establishing a psychological climate in the group.

The methods of management are:

1. Economic management methods are methods and techniques of influence based on economic relations.

2. Administrative methods of management create stable relations and relations of provisions regulating rights and responsibilities of units involved in the process of functioning of the mechanism.

3. Socio-psychological methods affect the psychological attitudes and emotional sphere of people's psyche by using moral incentives, special ways and conditions of communication, comparisons, and other techniques of influence.

The management tools are:

1. Project sheet - a document containing basic information about the project (name, rationale, objectives, participants, etc.).

2. Project plan that contains project control activities and events.

3. Project reports containing actual achievement of milestones, forecasting of milestones achievement, adjustment of further actions.

The control levers are:

1. Economic leverage, which is a system of resources and economic incentives.

2. Information leverage, which is consists of the correlation and interrelation of management decisions, planning, control, accounting, reporting, and document flow.

3. Administrative leverage is a system of distribution of rights and duties, which is reflected in administrative documents such as statutes, regulations, etc.

The principles on which this mechanism is based are presented in Figure 5. 


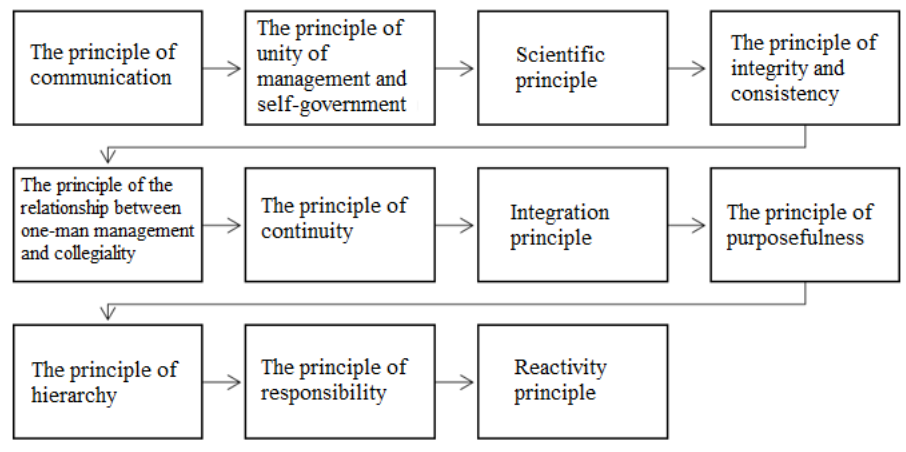

Fig. 5. Principles of the organizational and economic mechanism of $r \& d$ management in the university.

Let us consider each of the principles in more detail:

- The principle of communication. The effective functioning of a team depends on the quality of communication within it.

- The principle of unity of government and self-government. In accordance with this principle, management and self-governance should be combined at every level of management, from the top manager to the lowest performer.

- The principle of scientificity. Any rules, including management rules, must comply with objective laws and be based on the achievements of science and technology.

- The principle of integrity and consistency. This principle emphasizes that management activities are consistent, logical, mutually beneficial, and all functions are equally important.

- The principle of interdependence of one-man management and collegiality. This principle allows the clear interaction of all units of its vertical and horizontal, the coordination of all performers.

- Principle of continuity. The principle of continuity requires that the team be formed in such a way that an optimal age structure is constantly reproduced. The effectiveness of a team is greatly reduced when it includes only the older or only the younger generation.

- Principle of integration. Provides for the process of combining the efforts of all units to achieve the set goals and objectives.

- Principle of purposefulness. The principle of purposefulness implies that any management process begins with the definition of a specific goal that is characterized by measurability, controllability, and the real possibility of its achievement.

- Principle of hierarchy. Provides for a vertical division of management labor, i.e. allocation of management levels and subordination of lower management levels to higher ones.

- Principle of responsibility. This principle means creating a clear organizational structure; developing regulations on the rights and responsibilities of managers, job descriptions of executives; clear adoption of orders and instructions; conducting other organizational activities.

- Principle of reactivity. According to this principle, some action is determined by an external stimulus.

The listed principles serve as a methodological basis for the development of the strategy leading to the development of research activities of the university.

The internal impact on the proposed organizational and economic mechanism of research and development management in the university is evaluated using the SWOT matrix [13] (strengths, weaknesses, opportunities, and threats). The SWOT matrix is presented in Table 3: 
Table 3. SWOT matrix.

\begin{tabular}{|c|c|}
\hline $\begin{array}{c}\mathrm{S} \\
\text { (Strengths). }\end{array}$ & $\begin{array}{c}\mathrm{W} \\
\text { (Weaknesses) }\end{array}$ \\
\hline $\begin{array}{c}\mathrm{O} \\
\text { (Opportunities). }\end{array}$ & $\begin{array}{c}\mathrm{T} \\
\text { (Threats) }\end{array}$ \\
\hline
\end{tabular}

External impacts on the proposed organizational and economic mechanism of research management in the university are evaluated using the PESTEL matrix (political, economic, socio-cultural, technological, legal, and environmental impacts). The PESTEL matrix is presented in Table 4:

Table 4. PESTEL matrix.

\begin{tabular}{|c|c|c|}
\hline $\begin{array}{c}\mathrm{P} \\
\text { (Political factors) }\end{array}$ & $\begin{array}{c}\mathrm{E} \\
\text { (Economic factors) }\end{array}$ & $\begin{array}{c}\mathrm{S} \\
\text { (Socio-cultural } \\
\text { factors) }\end{array}$ \\
\hline $\begin{array}{c}\mathrm{T} \\
\text { (Technological } \\
\text { factors) }\end{array}$ & E & $\mathrm{L}$ \\
(Environmental impacts) & (Legal factors) \\
\hline
\end{tabular}

Let us consider all these factors in more detail:

$\mathrm{P}$ (Political factors) - taxes imposed by the authorities, legal and regulatory interventions in the market;

E (Economic Factors) - the general macroeconomic background, including economic growth, inflation, interest rates, and exchange rates;

S (Socio-cultural factors) - general social background, including trends related to population, types of consumption, and population distribution by age;

$\mathrm{T}$ (Technological Factors) - trends in R\&D and innovation affecting products and production as well as threats from substitute products;

E (Environmental Impacts) - weather and climate-related trends, the impact of climate change on your firm's operations and customer preferences;

L (Legal Factors) - trends in a legislative activity that affect a firm's operations and decisions there, including those related to hiring, health and safety environments, as well as antitrust, consumer protection, capital adequacy at financial institutions, and governance laws. [13]

The methodology for assessing and improving the performance of research groups of national research universities includes two components: assessing the performance of one research group and comparing its performance with the performance of other research groups. The methodology for assessing and improving the performance of research teams consists of 8 consecutive steps, the implementation of which will be able not only to form an idea of the current state of R\&D but also to make adjustments to its activities in order to improve it.

When assessing the performance of the scientific team the actual performance indicators of the scientific team shall be established. The actual performance of the research team is then measured by two indicators: the value of winning projects and the number of project applications submitted. It should be noted that depending on the level of project complexity and cost, each project carried out by the research team is assigned a weighting coefficient $\alpha$. Let's determine the weighting factor $\alpha$ in the project cost calculation and give it a value from 0 to 1 . The ranking of the weighting factor $\alpha$ is plotted in Table 5.

Table 5. Ranking of the weighting factor $\alpha$.

\begin{tabular}{|c|c|c|}
\hline No. & Weighting factor $\alpha$ & Project cost (rubles) \\
\hline
\end{tabular}




\begin{tabular}{|c|c|c|}
\hline 1. & 0.2 & up to $\$ 50,000$ \\
\hline 2. & 0.4 & $5,000,000-10,000,000$ \\
\hline 3. & 0.6 & $10,000,000-17,000,000$ \\
\hline 4. & 0.8 & $17,000,000-25,000,000$ \\
\hline 5. & 1 & more than $25,000,000$ \\
\hline
\end{tabular}

The assessment of the performance level of the scientific team by the value of the won project(s) is calculated according to the formula 1 :

Where,

$$
\text { РНГС }=\sum_{\mathrm{i}=0}^{\mathrm{n}} \frac{\mathrm{C}_{3} * \alpha_{\mathrm{i}}}{\mathrm{Cв}_{\mathrm{i}}}
$$

РНГс - performance of the research team (in terms of project cost);

Спз - the value of the won applications for the projects of the scientific group;

Св3 - value of all winning bids by projects;

$\alpha$ - weighting coefficient.

The assessment of the scientific team performance level by the number of submitted applications for participation in the project competitions is calculated by formula 2 :

Where,

$$
\text { РНГК }=\sum_{\mathrm{i}=0}^{\mathrm{n}} \frac{\mathrm{Kп}_{\mathrm{i}} * \alpha_{\mathrm{i}}}{\mathrm{KB}_{\mathrm{i}}}
$$

РНГК - performance of the scientific group (by the number of submitted applications);

Кпз - the number of scientific group applications submitted;

Квз - number of all submitted applications;

$\alpha$ - weighting coefficient.

Comparison of the performance of research teams is determined by a pairwise comparison method based on two criteria: the cost of the project and the number of applications submitted.

A categorical ranking of scientific groups from the highest to the lowest value is compiled on the basis of the results obtained in the performance evaluation of scientific groups. Subsequently, at the strategic management level, the results of the scientific teams' activities are analyzed and measures to improve their performance are developed. These activities are reflected in the university's research and development strategy through changes in mission and strategic, tactical, and operational objectives. These adjustments will affect both the activities of the research teams and the research activities of the university as a whole. (Figure 6)

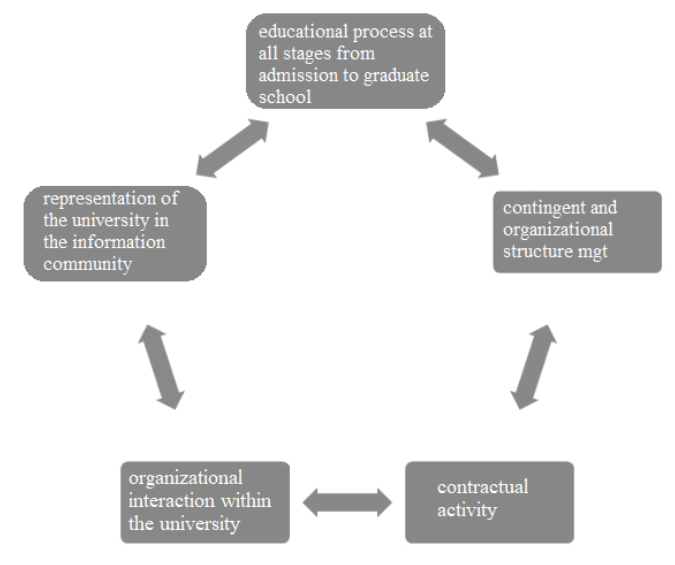

Fig. 6. Directions for improvement of the university strategy.

Continuous monitoring of the scientific teams at each stage of its operation is mandatory. 


\section{Conclusion}

Thus, the proposed mechanism of university research activity management is universal and can be applied in any higher education institution. This mechanism differs from existing developments:

1. the ability to evaluate $R \& D$ activities, based on the analysis of performance indicators of research teams;

2. extension of scientific and methodological bases of university research activity management to ensure the university leadership in research and development, as well as the formation of the system of training and professional development of students, postgraduates, and scientific-pedagogical staff.

Based on the above, the purpose of the study has been achieved.

\section{References}

1. Federal Law "On Science and State Scientific and Technical Policy" of 23.08.1996 N 127-FZ (last edition)

2. M.A. Kiseleva, Review-analytical journal, scientific-practical j. 5 (65), 11 (2019)

3. A. Biloshchytskyi, A. Kuchansky, Yu. Andrashko, et al., Eastern-European Journal of Enterprise Technologies 3 (2 (87)), 4 (2017). DOI 10.15587/1729-4061.2017.103651.

4. D. S. Tereshchenko, V. S. Shcherbakov, Economy of Region 17 (1), 223 (2021). DOI 10.17059/ekon.reg.2021-1-17.

5. I. Shcheglova, Yu. Koreshnikova, O. Parshina, Educational Studies. Moscow 1, 264 (2019). DOI 10.17323/1814-9545-2019-1-264-289.

6. V. Shebashev, L. Nizova, E. Andreeva, et al., Journal of Applied Engineering Science 18 (3), 333 (2020). DOI 10.5937/jaes18-25844.

7. K.A. Kholodkova, Modern Scientific Research and Innovation 5 (2018)

8. A.V. Popkov, I.M. Velm, O.P. Druzhakina, S.V. Shirobokov, Fundamentals of students' scientific activity: a textbook for university students, 228 p. (Izhevsk: Publishing house "Udmurt University", 2019)

9. M. V. Larionova, Bulletin of international organizations 1 (32), 4 (2017)

10. V.D. Zelensky, Fundamentals of Scientific Research, Krasnodar., 111 p. (2017)

11. L.A. Vitvitskaya, Development of interaction between the subjects of the educational process of the university: Author's abstract. dis. Cand. ped. Sciences: Orenburg State. University, Orenburg, 40 p. (2018)

12. N.L. Ketoeva, M.A. Kiseleva, V.K. Boiler room, Bulletin of SRSTU (NPI) 4, 37 (2020)

13. E. V. Ponomareva, Scientific journal: Economics and society 11-2 (30), 264 (2019)

14. O. I. Vaganova, A. V. Lapshova, M. M. Kutepov, et al., Amazonia Investiga 9 (25), $369(2020)$

15. Site of the Federal State Statistics Service of the Russian Federation. https://www.gks.ru/.

16. S. L. Troyanskaya, Fundamentals of the competence-based approach in higher education: textbook, 176 p. (Izhevsk: Publishing Center "Udmurt University", 2016)

17. N. L. Ketoeva, M. A. Kiseleva, M. T. Zargaryan, E. A. Sysoeva, Economics and Entrepreneurship 8 (121), 1297 (2020) 
18. R.I. Gabitov, L. Yu. Emaletdinova, Models and methods of development of automated systems of organizational management: monograph, 120 p. (K .: RIC "School", 2007) 